\title{
Biostimulant and Nematicidal Effect of Trichoderma harzianum Rifai and Aqueous Extract of Azadirachta indica A. Juss. in Solanum lycopersicum L.
}

\author{
Yoerlandy Santana Baños ${ }^{1, *}$, Armando del Busto Concepción ${ }^{1}$, Ivan Paneque Torres ${ }^{2}$, \\ Irisley Aguiar González ${ }^{3}$, Michel Ruiz Sanchez ${ }^{4}$, Edenys Miranda Izquierdo $^{1}$, Adanay Cándano Sánchez ${ }^{1}$, \\ Lisandra Hernández Guanche ${ }^{1}$
}

${ }^{1}$ Department of Agricultural Sciences, University of Pinar del Río, Cuba

${ }^{2}$ Department of Mountain Agronomy, University of Pinar del Río, Cuba

${ }^{3}$ Agropecuaria "Augusto César Sandino" Agricultural Company, Pinar del Río, Cuba

${ }^{4}$ National Institute of Agricultural Sciences, San José de las Lajas, Mayabeque, Cuba

Copyright $\bigcirc 2017$ by authors, all rights reserved. Authors agree that this article remains permanently open access under the terms of the Creative Commons Attribution License 4.0 International License

\begin{abstract}
The experiment was carried out with the objective of evaluating the biostimulating and nematicidal effect of Trichoderma harzianum Rifai "strain A-34" and aqueous extract of Azadirachta indica A. Juss. (neem) in Solanum lycopersicum L. (tomato) cv. "PR-92". Two trials were developed, the first in the seed germination process and the second in potting conditions for the treatments interaction and the inoculation of Meloidogyne spp. with tomato seedlings. The results showed that tomato seeds $\mathrm{cv}$. "PR-92" treated with T. harzianum "A-34" and aqueous extract of neem leaves did not affect the percentages of germination, however, the combined use of the preparations promote the seedlings growth. It was also corroborated that the seedlings infested with Meloiodgyne spp. showed lower means for stem length, total fresh mass and dry mass variables, compared to non-infested ones. As for the regulation of Meloidogyne spp., a reduction of the gill index was achieved in $53.5 \%, 38.5 \%$ and $61.5 \%$ for treatments where $T$. harzianum, neem and their combination were respectively applied with significant differences respect to control.
\end{abstract}

Keywords Meloidogyne, Tomato, Trichoderma, Neem

\section{Introduction}

The production and fruit quality in tomato crops depends on an adequate control of fungi, phytopathogenic bacteria and insects that damage foliage and fruits, also the root-knot nematodes and weeds that compete with plants for moisture and nutrients [1]. Phytopathogenic nematodes are at the forefront of pests affecting this crop in the world, especially galls formers (Meloidogyne spp.). Moosavi [2] states that cause $12.3 \%$ losses in agriculture in the world, and around 5\% of losses are attributed to Meloidogyne spp.; considered as important pests of many cultivated plants [3]. The root nematode (Meloidogyne incognita) is one of the major limiting factors affecting growth and yield, causing an estimated \$ 100 billion loss per year worldwide [4].

At present, the use of biological mediums and botanical preparations are booming as non-chemical alternatives in the management of Meloidogyne spp., because they reduce the economic-environmental impact and frequently promote the plants development [5].

One of the biological alternatives for the Meloidogyne spp. management is the use of antagonist fungi of the genus Trichoderma. Several species of Trichoderma have been evaluated as biological control agents against nematodes in various crops and experimental conditions, emphasizing among the mechanisms involved the parasitism, enzymatic lysis, antibiosis and induced resistance [6]. The increase of plant growth, yield and other parameters could be attributed to the release of growth promoting substances by Trichoderma spp. and other biological agents studied in the control of M. incognita [7].

The use of plants with properties or characteristics that promote the regulation of populations of Meloidogyne spp., constitutes a very promissory practice for the management of this pest, especially for the development reached in Cuba urban agriculture. An example of a plant with nematicidal activity is Azadirachta indica A. Juss., plant belonging to the family Meliaceae, with biological activities widely used in agriculture for the management of insect pests [8] and nematodes [9]. Several authors reported reduction in gill index by Meloidogyne spp. through biodesinfection with foliage of $A$. indica [10] and different doses of $A$. indica 
wastes [11], although they recommend to deepen the effect over plant growth.

Taking into account the above, the research was carried out with the objective of evaluating the biostimulating and nematicidal effect of $T$. harzianum "strain A-34" and aqueous extract of $A$. indica in $S$. lycopersicum.

\section{Materials and Methods}

The research was carried out at the Microbiology Laboratory and Experimental Areas of the Forestry and Agriculture Sciences Faculty in University of Pinar del Río, Cuba, located at $22^{\circ} 24 ' 48^{\prime \prime} \mathrm{N}$ and $83^{\circ} 41^{\prime} 16^{\prime}$ 'W, between September and December 2014.

\subsection{Description of the Experiment I}

The effect of T. harzianum "strain A-34" and aqueous extract of $A$. indica on germination of tomato seeds was evaluated, considering the treatments described in table 1 .

Table 1. Description of the treatments in the germination experiment

\begin{tabular}{|c|c|c|}
\hline Number & Treatments & Tag \\
\hline 1 & $\begin{array}{c}\text { Seeds immersed for two hours in conidial solution } \\
\text { of } T . \text { harzianum "strain A-34" at a concentration of } \\
2.5 \%(\mathrm{w} / \mathrm{v}) \text { of the solid bioprepared with distilled } \\
\text { water. }\end{array}$ & $\mathrm{T}$ \\
\hline 2 & $\begin{array}{c}\text { Seeds immersed for two hours in aqueous extract of } \\
\text { leaves of } A \text {. indica } \text { at } 5 \%(\mathrm{w} / \mathrm{v}) .\end{array}$ & $\mathrm{N}$ \\
\hline 3 & Seeds submerged for two hours in distilled water. & $\mathrm{C}$ \\
\hline
\end{tabular}

The plant material used was S. lycopersicum cv. "PR-92". After treatment, the seeds were placed on filter paper for drying in laboratory conditions at $25.6^{\circ} \mathrm{C}$ temperature. Six hours later they were randomly distributed into Petri dishes of $10 \mathrm{~cm}$ diameter, using five plates per treatment and 50 seeds per plate. They were subjected to a dark chamber for 12 hours and subsequently to a light and dark regime at the same period of time up to 94 hours after sowing, with evaluations at six hour intervals.

Germination was quantified at six-hour intervals and the germination percent (GP), germination rate index (GRI) [12] and mean germination time (MGT) [13] were evaluated. Calculations were made by the formulas described below.

$$
\begin{gathered}
\text { GP }(\%)=\frac{X}{S} * 100 ; \\
\text { GRI }=\frac{x_{1}}{t_{1}}+\frac{x_{2}}{t_{2}}+\ldots .+\frac{x_{n}}{t_{n}} ;
\end{gathered}
$$$$
\text { MGT (hours) }=\left[\left(\mathrm{x}_{1} \mathrm{t}_{1}\right)+\left(\mathrm{x}_{2} \mathrm{t}_{2}\right)+\ldots . .\left(\mathrm{x}_{\mathrm{n}} \mathrm{t}_{\mathrm{n}}\right)\right] / \mathrm{X}_{\mathrm{n}}
$$

Legend: (X) number of germinated seeds, (S) total seed, $(\mathrm{x} 1, \mathrm{x} 2 \ldots \mathrm{xn})$ number of germinated seeds in the count corresponding to $\mathrm{t} 1, \mathrm{t} 2 \ldots \mathrm{tn},(\mathrm{t})$ time (hours) elapsed since sowing until the count, $(\mathrm{Xn})$ total germinated seeds at the last count.

\subsection{Description of the Experiment II.}

The experiment was developed in climatic conditions characterized by temperatures between 18.2 and $28.9{ }^{\circ} \mathrm{C}$, with an average of $22.6{ }^{\circ} \mathrm{C}$, and average relative humidity of $79 \%$. The plant material used was $S$. lycopersicum cv. "PR-92". Four treatments were established in $S$. lycopersicum plants with and without inoculation of Meloidogyne spp., following a completely randomized design with factorial arrangement (Table 2).

\begin{tabular}{|c|c|c|}
\hline Number & Treatments & Tag \\
\hline 1 & $\begin{array}{c}\text { Applications of } T \text {. harzianum in } S . \text { lycopersicum } \\
\text { seedlings. }\end{array}$ & $\mathrm{T}$ \\
\hline 2 & $\begin{array}{l}\text { Applications of aqueous extract of leaves of } A \text {. } \\
\text { indica at } 5 \%(\mathrm{w} / \mathrm{v}) \text { in } S \text {. lycopersicum seedlings. }\end{array}$ & $\mathrm{N}$ \\
\hline 3 & $\begin{array}{c}\text { Applications of } T \text {. harzianum and aqueous extract } \\
\text { of leaves of } A \text {. indica at } 5 \%(\mathrm{w} / \mathrm{v}) \text { in } S . \\
\text { lycopersicum seedlings. }\end{array}$ & $\mathrm{T}+\mathrm{N}$ \\
\hline 4 & Seedlings of S. lycopersicum without treatment. & $\mathrm{C}$ \\
\hline
\end{tabular}

Table 2. Treatments evaluated in experiment II.

Twenty pots with a capacity of $900 \mathrm{~g}$ of substrate were used in each treatment, 10 with inoculation of nematodes (Meloidogyne spp.) in the rhizosphere and the remaining ones without inoculation of nematodes. As a substrate, a mixture of Ferralitic Yellowish Leached Soil [14], peat and rice husk, was used to obtain a ratio of 70: 20: 10, respectively. In soil disinfection, $4 \%$ formaldehyde was used for 72 hours, whereas peat and rice husk were sterilized at a temperature of $121^{\circ} \mathrm{C}$ in an oven during four hours.

Sowing was done manually, placing four seeds per bag, leaving two seedlings per bag after germination with uniformity in the choice of the same.

The evaluations were carried out 35 days after germination, at which time 10 seedlings were randomly extracted from each treatment and processed in the Laboratory of Microbiology at Pinar del Río University. It was determination the galls index [15], shoot length and diameter, leaf number, total fresh mass and total dry mass, foliar and root mass.

\subsection{Obtaining, Preparation and Application of Trichoderma and Neem.}

The T. harzianum "strain A-34" bioprepared was obtained at the Reproduction of Entomophages Center of "La Conchita", in Pinar del Río municipality. It had a concentration of $1.9 \times 10^{9} \mathrm{cfu} \mathrm{ml}^{-1}, 100 \%$ purity and $96 \%$ viability. The applications were carried out three days before planting and two others every seven days, using a dose of 10 $\mathrm{ml} /$ pot of conidial solution, obtained at a concentration of $2.5 \%(\mathrm{w} / \mathrm{v})$ of the solid bioprepared with distilled water.

In the preparation of the aqueous extract was used neem leaf collected from trees located at $22^{\circ} 25^{\prime} 11$ "N 83 $41^{\prime} 17^{\prime \prime}$ $\mathrm{W}$, in organoponics of the municipality of Pinar del Río. The foliage was subjected to a drying process under ambient conditions, in the shadow, until losing between 90 and $95 \%$ 
humidity. The preparation was carried out in a glass vessel, with a proportion of $50 \mathrm{~g} \mathrm{l}^{-1}$ of crushed foliage in distilled water during 8 hours, later the extract obtained was filtered. Three applications were carried out at a rate of $15 \mathrm{ml} /$ pot from five days after germination with a seven day interval.

\subsection{Preparation and Application of the Inoculum of Meloidogyne spp.}

Samples of Ferralitic Yellowish Leached Soil [14] were collected from the experimental area of the Pinar del Río University, where infestation by Meloidogyne spp. in S. lycopersicum was detected. The population of Meloidogyne spp. was extracted through bioassay method by indicator plant, using Cucurbita maxima. The analysis of the species composition showed the presence of $M$. incognica and Meloidogyne sp. to a less extent. The application of the inoculum was carried out in the rhizosphere five days after germination, guaranteeing $0.5 \mathrm{~J}_{2}$-eggs per gram of soil in each pot.

\subsection{Statistical Analysis Employed}

A simple and multivariate analysis of variance was performed using the Duncan Multiple Rank test for mean comparison, with a confidence level of $95 \%(\mathrm{p} \leq 0.05)$. Linear regression analysis was also applied for germination dynamics. The statistical program SPSS version 21.0 for Windows was used.

\section{Results}

In experiment I, germination was initiated 30 hours after sowing for all treatments, with a linear increase up to 66 hours expressed in coefficients of determination $\left(\mathrm{R}^{2}\right)$ higher than $97 \%$, although the germination percent increased significantly at 48, 54 and 60 hours with $T$. harzianum "strain A-34", whereas it was reduced in seeds treated with neem aqueous extract. The germination percent at 66 hours was $91.7 \%, 86.5 \%$ and $84.5 \%$ in treatments $\mathrm{T}, \mathrm{C}$ and $\mathrm{N}$, respectively.

Table 3 shows similar values of germination rate index (GRI) in treatments T, N and C (1.5, 1.29 and 1.41), although the mean germination time (MGT) was affected in the treatment $\mathrm{N}$ (51.13), with significant differences regarding $\mathrm{T}$ and $C$ (47.2 and 48.8). In addition, similar results were achieved in percentages of germination at 96 hours, with values above $96 \%$.

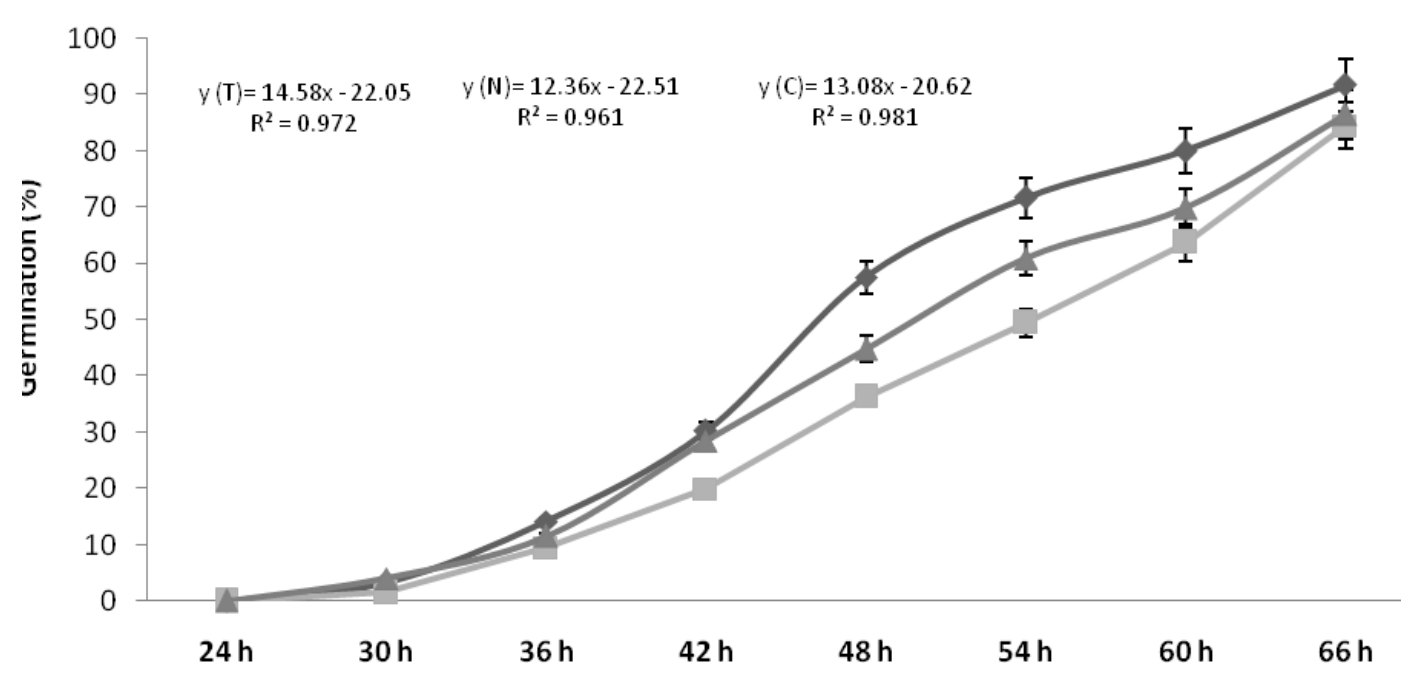

Figure 1. Effect of the treatments in the germination experiment

Table 3. Germination rate index (GRI), mean germination time (AGP) and germination percentage (GP) in treatments evaluated.

\begin{tabular}{|c|c|c|c|}
\hline Treatments & GRI & AGP (hours) & $\begin{array}{l}\text { GP (96 } \\
\text { hours) }\end{array}$ \\
\hline $\mathrm{T}$ & 1.50 & $47.19 \mathrm{~b}$ & 98.67 \\
\hline $\mathrm{N}$ & 1.29 & $51.13 \mathrm{a}$ & 96.17 \\
\hline $\mathrm{C}$ & 1.41 & $48.78 \mathrm{~b}$ & 97.05 \\
\hline $\mathrm{SE}$ & $0.112 \mathrm{~ns}$ & $0.061 *$ & $0.743 \mathrm{~ns}$ \\
\hline
\end{tabular}

$n s$ : not significant, * significant for $\mathrm{p} \leq 0.05$ 


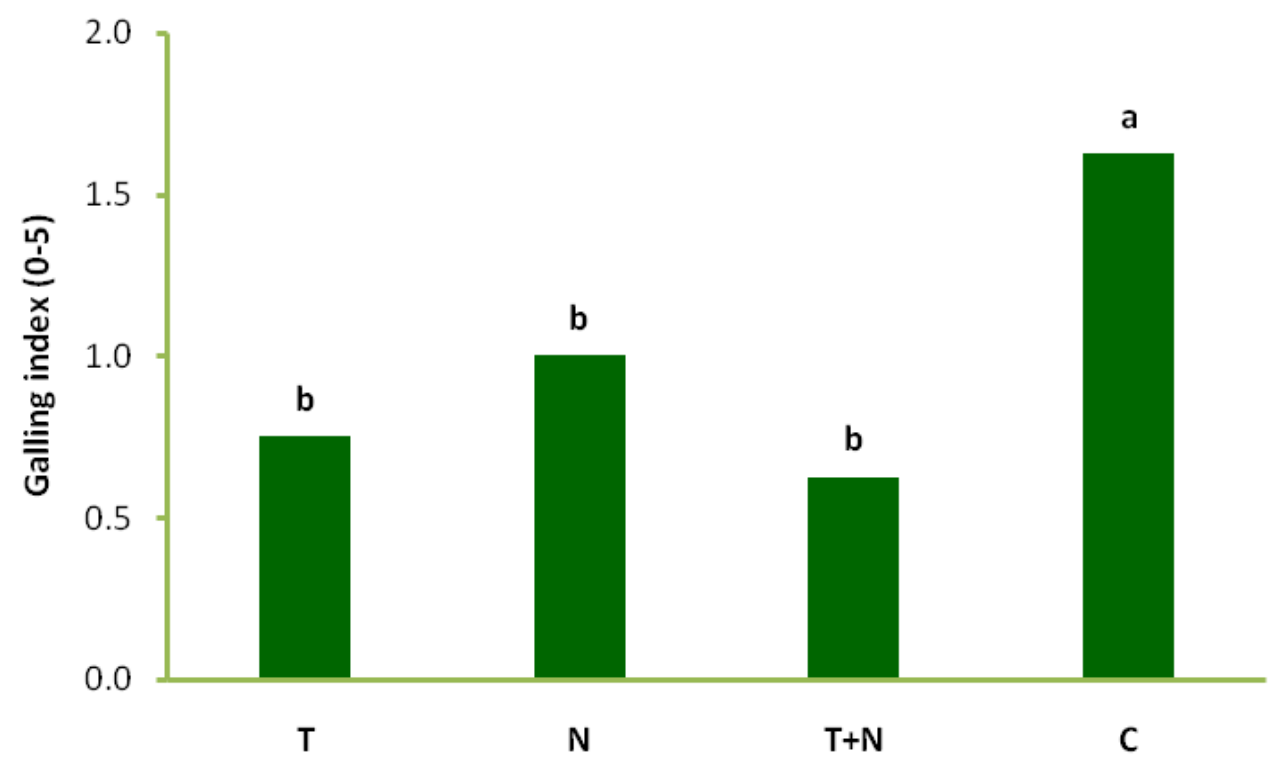

Figure 2. Effect of the treatments in the galls index

In experiment II the galls index was reduced by Meloidogyne spp. in $53.5 \%, 38.5 \%$ and $61.5 \%$ for $\mathrm{T}, \mathrm{N}$ and $\mathrm{T}+\mathrm{N}$ treatment, respectively, with significant differences over control (figure 2), where a galls index of 1.6 grade was determined.

The analysis of variance for the effect of the evaluated factors and their interaction on the growth variables of $S$. lycopersicum cv. "PR-92" is presented in table 4. Except for shoot diameter, leaf number and leaf dry mass, the other variables showed significant differences between infested plants and those not infested with Meloidogyne spp. For the treatment factor, there was a significant effect over all variables evaluated. The interaction was only significant for shoot length, indicating strong influence of the factors evaluated on this variable.

Table 4. Analysis of variance ( $\mathrm{F}$ value) for growth variables (experiment II)

\begin{tabular}{|c|c|c|c|c|c|c|c|}
\hline FACTORS & $\begin{array}{c}\text { Shoot length } \\
(\mathrm{cm})\end{array}$ & $\begin{array}{c}\text { Shoot diameter } \\
(\mathrm{mm})\end{array}$ & $\begin{array}{c}\text { Leaf } \\
\text { number }\end{array}$ & $\begin{array}{c}\text { Total fresh } \\
\text { weight }(\mathrm{g})\end{array}$ & $\begin{array}{c}\text { Total dry } \\
\text { weight }(\mathrm{g})\end{array}$ & $\begin{array}{c}\text { Leaf dry } \\
\text { weight }(\mathrm{g})\end{array}$ & $\begin{array}{c}\text { Root dry } \\
\text { weight }(\mathrm{g})\end{array}$ \\
\hline Nematode & $13.47^{* *}$ & $1.95 \mathrm{~ns}$ & $1.12 \mathrm{~ns}$ & $4.21^{*}$ & $5.98^{*}$ & $3.84 \mathrm{sn}$ & $22.85^{* *}$ \\
\hline Treatments & $14.97^{* *}$ & $4.68^{*}$ & $5.12^{*}$ & $10.34^{* *}$ & $8.64 * *$ & $8.71^{* *}$ & $6.84^{* *}$ \\
\hline Nem. ${ }^{*}$ Treat. & $2.97^{*}$ & $0.50 \mathrm{~ns}$ & $0.13 \mathrm{~ns}$ & $2.21 \mathrm{~ns}$ & $0.81 \mathrm{~ns}$ & $0.59 \mathrm{~ns}$ & $2.66 \mathrm{~ns}$ \\
\hline SE & .323 & .005 & .079 & .144 & 0.011 & 0.009 & 0.002 \\
\hline
\end{tabular}

** and *: significant differences for $\mathrm{p} \leq 0.01$ and $\mathrm{p} \leq 0.05$, ns: not significant

Table 5 shows the average values of the growth variables in S. lycopersicum cv. "PR-92" with and without nematode inoculation (Meloidogyne spp.). It should be noted that all variables reached lower means in infested plants (with nematodes) than in non-infested plants (without nematodes), although the greatest reduction in growth was expressed in shoot length (10.4\%), total fresh weight (12.9\%), dry weight (17.3\%), dry leaf weight (14.2\%) and dry weight $(36.4 \%)$.

Table 5. Effect of nematode inoculation on the growth of S. lycopersicum cv. "PR-92"

\begin{tabular}{|c|c|c|c|}
\hline Growth Variables & With nematodes & Without nematodes & Sig. \\
\hline Shoot length $(\mathrm{cm})$ & 12.790 & 14.275 & .001 \\
\hline Shoot diameter $(\mathrm{cm})$ & .337 & .349 & .172 \\
\hline Leaf number & 3.350 & 3.500 & .297 \\
\hline Total fresh weight $(\mathrm{g})$ & 2.905 & 3.335 & .048 \\
\hline Total dry weight $(\mathrm{g})$ & .196 & .237 & .020 \\
\hline Leaf dry weight $(\mathrm{g})$ & .175 & .204 & .059 \\
\hline Root dry weight $(\mathrm{g})$ & .021 & .033 & .000 \\
\hline
\end{tabular}

Table 6 shows the effect of treatments on the growth of S. lycopersicum cv. "PR-92". Higher means could be observed in seedlings treated with Trichoderma $(\mathrm{T})$ and their combination with neem $(\mathrm{T}+\mathrm{N})$, which showed significant differences in reference to those treated with neem $(\mathrm{N})$ and untreated $(\mathrm{C})$. Application of aqueous neem extract did not affect the growth of S. lycopersicum cv. "PR-92", since it shows means similar to the control in the evaluated variables. 
Table 6. Effect of treatments on the growth variables of S. lycopersicum cv. "PR-92"

\begin{tabular}{|c|c|c|c|c|c|c|c|}
\hline Treatments & $\begin{array}{c}\text { Shoot length } \\
\mathbf{( c m )}\end{array}$ & $\begin{array}{c}\text { Shoot } \\
\text { diameter } \\
\mathbf{( c m}\end{array}$ & $\begin{array}{c}\text { Leaf } \\
\text { number }\end{array}$ & $\begin{array}{c}\text { Total fresh } \\
\text { weight (g) }\end{array}$ & $\begin{array}{c}\text { Total dry } \\
\text { weight }(\mathbf{g})\end{array}$ & $\begin{array}{c}\text { Leaf dry } \\
\text { weight (g) }\end{array}$ & $\begin{array}{c}\text { Root dry } \\
\text { weight (g) }\end{array}$ \\
\hline $\mathrm{T}$ & $14.26 \mathrm{a}$ & $.35 \mathrm{ab}$ & $3.70 \mathrm{a}$ & $3.61 \mathrm{a}$ & $.256 \mathrm{a}$ & $.225 \mathrm{a}$ & $.030 \mathrm{ab}$ \\
\hline $\mathrm{N}$ & $12.46 \mathrm{~b}$ & $.32 \mathrm{~b}$ & $3.20 \mathrm{~b}$ & $2.43 \mathrm{~b}$ & $.170 \mathrm{~b}$ & $.151 \mathrm{~b}$ & $.019 \mathrm{c}$ \\
\hline $\mathrm{T}+\mathrm{N}$ & $15.38 \mathrm{a}$ & $.37 \mathrm{a}$ & $3.70 \mathrm{a}$ & $3.78 \mathrm{a}$ & $.263 \mathrm{a}$ & $.228 \mathrm{a}$ & $.034 \mathrm{a}$ \\
\hline $\mathrm{C}$ & $12.03 \mathrm{~b}$ & $.33 \mathrm{~b}$ & $3.10 \mathrm{~b}$ & $2.66 \mathrm{~b}$ & $.179 \mathrm{~b}$ & $.154 \mathrm{~b}$ & $.025 \mathrm{bc}$ \\
\hline $\mathrm{SE}$ & .323 & .005 & .079 & .144 & .011 & .009 & .002 \\
\hline
\end{tabular}

\section{Discussion}

Seed treatment of $S$. lycopersicum cv. "PR-92" with $T$. harzianum "strain A-34" and aqueous extract of 5\%(w/v) neem leaves has caused a linear growth in the germination dynamics, without affecting the germination percentage, even though between 42 and 60 hours after sowing significantly lower means were manifested when the seeds were treated with neem leaf aqueous extract. Germination rate and mean germination time indexes were also verified with little variability, although in the last one it was observed a reduction in seeds treated with Trichoderma and an increase of 2.35 hours with aqueous extract of neem leaf. The use of T. harzianum "A-34 strain" promote the germination, a result that could be related to the reports on the production of growth factors (auxins, gibberellins and cytokinins) by $T$. harzianum, which are released into the medium and stimulate germination and plant development [16-17], whereas the results with the aqueous extract of neem leaf suggest that the uniformity of germination is not affected. The effect of $T$. harzianum during 15 days after inoculation on passion fruit seeds (Passiflora adulos Degener), showed significant increases in germination after four days after inoculation [18]. Recent study on the effect of T. harzianum "strain A-34" inoculated in seeds of $S$. lycopersicum cv. "Vyta", reports absolute germination percent higher than control [19].

The use of T. harzianum "strain A-34" and aqueous extract of neem leaves evidenced a reduction in the agglutination index by Meloidogyne spp., although the infestation provoked with the level of inoculum used is considered low, however it is be observed that agglutination index $\leq$ to grade 2 caused significant reductions in shoot length, total fresh mass and total and radical dry mass of S. lycopersicum cv. "PR-92", which corroborates the phytoparasite action of Meloidogyne spp., Although it would be opportune to evaluate different levels of inoculum.

It was also possible to observe higher growth of $S$. lycopersicum cv. "PR-92" in seedlings treated with Trichoderma and its combination with aqueous extract of neem, an aspect that is favorable in the search of alternatives that can be integrated in the management of Meloidogyne spp. and that at the same time can promote, or not affect, the growth of plants. The results corroborate the biostimulating effect of Trichoderma and suggest that aqueous extract concentrations of neem $\leq 5 \%$ do not affect the growth of $S$. lycopersicum cv. "PR-92".

In the treatments where $T$. harzianum was used, it was reduced the number of galls compared with the control [20]. Several authors report a significant reduction of the agglutination index by Meloidogyne spp. with different forms of use of neem preparations in S. lycopersicum [2, 11, 21]. Applications of neem cake extract and T. harzianum caused a reduction in the number of galls and egg masses in $70.3 \%$ and $59.3 \%$, respectively [22].

Trichoderma species may induce changes in plant morphology and development, with increasing root and/or foliar biomass being the most common expression of growth promotion [23]. In treatments where $T$. harzianum was applied, increases were reported in relation to the control for the total fresh and dry mass of the plants [7]. There was also an increase in shoot length with different forms of use of neem preparations in tomato plants inoculated with $M$. javanica [21], although there were no significant differences for this variable in S. lycopersicum cv. "Campbell 28" when used in biodesinfection of soil infested with Meloidogyne spp. [11].

\section{Conclusions}

The results evidenced biostimulating effect of $T$. harzianum "strain A-34" on the germination and growth of $S$. lycopersicum cv. PR-92, whereas the aqueous extract of 5\% neem leaf does not limit these processes, although it causes a delay in the seed germination without affecting the germination percentage. A regulatory effect on Meloidogyne spp. with the use of Trichoderma, neem and their combination suggests deepening the use of these biopreparates as alternatives that offer different benefits when used in the management of plant parasitic nematodes.

\section{REFERENCES}

[1] A. A. Csizinszky, D. J. Schuster, J. B. Jones, J. C. Van Lenteren. Crop protection. En: Tomatoes. Crop production science in horticulture series. EpHeuvelink (ed.). CABI publisher, 2005.

[2] M. R. Moosavi. Nematicidal effect of some herbal powders and their aqueous extracts against Meloidogyne javanica. Nematropica, 42(1): 48-56, 2012. 
[3] J. Lamovšek, G. Urek, J. Trdan. Biological Control of Root-Knot Nematodes (Meloidogyne spp.): Microbes against the Pests. Acta Agriculturae Slovenica, 101(2): 263-275, 2013.

[4] T. Mukhtar, M. Arshad, M. Zameer, M. Naveed. Evaluation of resistance to root-knot nematode (Meloidogyne incognita) in okra cultivars. Crop Protection, 56(1): 25-30, 2014.

[5] Y. Santana, A. Del Busto, M. G. Rodríguez, F. L. Rodríguez, D. Maqueira. Interaction of Trichoderma harzianum Rifai and Azadirachta indica A. Juss on a population of Meloidogyne spp. in seedlings of Solanum lycopersicum L. Rev. Protección Veg., 31(2): 114-119, 2016.

[6] E. Sharon, I. Chet, Y. Spiegel. Trichoderma as Biological Control Agent. En Biological Control of plant parasitic nematodes: Building coherence between microbial ecology and molecular mechanisms. Progress in Biological Control.11. K. Davies and Y. Speigel (Eds.). Springer Science+ Business Media. pp. 183-201, 2011.

[7] D. M. Preethi, S. Bommalinga, R. S. Pavithra, N. G. Ravichandra, B. M. R. Reddy, S. Syeda. Evaluation of various bio-agents for their efficacy against Meloidogyne incognita on growth and development of tuberose (Polianthes tuberosa L.). Global Journal of Bio-science and Biotechnology, 5(1): 125-127, 2016.

[8] K. Jabran, M. Farooq, Z. A. Cheema, A. Wahid, K. H. M. Siddique. The role of allelopathy in agricultural pest Management. Pest Manag Sci., 67: 493-506, 2011.

[9] J. Salar, H. Shervin, R. Kamran, E. Ali. Comparing neem extract with chemical control on Fusarium oxysporum and Meloidogyne incognita complex of tomato. Advances in Environmental Biology. Code: 7IRAN Date: Jul 1, 2011.

[10] L. Gómez, M.G. Rodríguez, L. Díaz-Viruliche, E. González, F. Wagner. Evaluation of cikron-h by-products for soil biodisinfection. Nematicidal effects. Rev. Protección Veg., 21(3): 178-185, 2006.

[11] M. G. Rodríguez, L. Gómez, D. Hernández-Ochandía, R. Enrique, I. Miranda, O. Pino. Effect of neem (Azadirachta indica A. Juss) waste on Meloidogyne spp. population in soil. Rev. Protección Veg., 27(3): 197-201, 2012.

[12] R. Brown and D. Mayer. Representing cumulative germination. 1. A critical analysis of single-value germination indices. Ann. Bot. 61, 117-125, 1988.
[13] J. García, J. Monteith, G. Squire. Time, temperature, and germination of pearl millet (Pennisetum typhoides S. \& H.). J. Exp. Bot., 33: 288-296, 1982.

[14] A. Hernández, J. M. Pérez, D. Bosch, L. Castro. Classification of Cuban Soils 2015. Editions INCA, Mayabeque, Cuba, p. 64, 2015 .

[15] A. L. Taylor and J. B. Sasser. Biology, Identification and control of root-knot nematodes (Meloidogyne species). 111. Dept. Pl. Pathol. N. C. State Univ, Raleigh. 1978.

[16] C. Altomare, W. A. Norvell, T. Björkman, G. E. Harman. Solubilization of phosphates and micronutrients by the plant-growth-promoting and biocontrol fungus Trichoderma harzianum Rifai 1295-22. Appl. Environ. Microb., 65(7): 2926-2933, 1999.

[17] H. Valencia, J. Sánchez, N. Valero. Production of indoleacetic acid by phosphate solubilizing microorganisms present in the rhizosphere of Espeletia grandiflora and Calamagrostis effuse del Páramo el Hail. Pp. 177-193. In: M. Bonilla (ed.). Adaptive strategies of páramo and high Andean forests in the eastern Cordillera of Colombia. Unibiblos, Bogotá. 2005.

[18] J. G. Cubillos-Hinojosa, N. Valero, L. Mejía. Trichodermaharzianum as a plant growth promoter in yellow passion fruit (Passiflora edulis var. flavicarpa Degener). Agronomía Colombiana, 27(1): 81-86, 2009.

[19] Y. Santana, A. del Busto, Y. González, I. Aguiar, S. Carrodeguas, P. L. Páez, G. Díaz. Efect of T. harzianum and FitoMas- $E^{\circledR}$ as bioestimulants of the germination and growth of seedlings of tomato. Centro Agrícola, 43 (3): 5-12, 2016.

[20] V. Kumar, A.U. Singh, R.K. Jain. Comparative efficacy of bioagents as seed treatment for management of Meloidogyne incognita infecting okra. Nematol. Medit., 40: 209-211, 2012.

[21] F. A. Almeida, F. A. Petter, V.C. Siqueira, F. Alcântara, A.U. Alves, M. L. T. Leit. Preparation methods of plant extracts on Meloidogyne javanica in tomato. Nematropica, 42: 9-15, 2012.

[22] S. K. Zareena and V. Vanita. Root-knot disease and its management in brinjal. Global Journal of Bio-science and Biotechnology, 3(1): 126-127, 2014.

[23] A. Stewart and R. Hill. Applications of Trichoderma in Plant Growth Promotion. En: Biotechnology and Biology of Trichoderma. V. Gupta, M. Schmoll, A. Herrera-Estrella, R. Upadhyay, I. Druzhinina and M. Tuohy (Editors-Elsevier). pp. 415-428, 2014. 